\title{
Scheelite in Malene supracrustals of the Ivisârtoq area, southern West Greenland
}

\author{
Peter W. Uitterdijk Appel
}

In 1982 the first traces of scheelite were found in the Godthåbsfjord area in heavy mineral concentrates from stream sediments. The same year the first in situ scheelite occurrences were found. In the following year a stream-sediment sampling programme was carried out in the area and in the area to the south. This programme demonstrated that scheelite is a frequent constituent of the $3800 \mathrm{~m}$.y. old Isua supracrustal rocks and in the 3300 to 3000 m.y. old Malene supracrustals, whereas the gneisses in the Nuuk/Godthåb area are barren. The Malene supracrustal rocks, which form extensive outcrops, are the larger of the two supracrustal belts, and outcrops are found scattered over an area of at least $35000 \mathrm{~km}^{2}$.

During the field season of 1986 stream sediment samples were collected in the Ivisârtoq area of the inner Godthåbsfjord region, and they proved to contain high amounts of scheelite. It was thus decided to carry out field work with ultra-violet light, but early snow precipitation prevented any field work. During the field season the following year, another attempt was made to carry out field work with ultra-violet light in the Ivisârtoq area.

\section{Geology of the Ivisârtoq area}

The Ivisârtoq area has been mapped in detail by Chadwick (1986). The following brief account is based on his work combined with additional field information collected in 1987.

The Ivisârtoq area consists of Amîtsoq and Nûk gneisses, Malene supracrustal rocks, intrusive gabbroanorthosites, pegmatites and a number of late dykes.

The Malene supracrustal rocks which form major outcrops in the area consist of a thick sequence of mafic volcanic rocks with thin intercalated sedimentary hori-zons together with thin ultramafic intrusives.

The Malene sequence at Ivisârtoq has been subdivided into a lower pillow-lava sequence, which is separated from an upper pillow-lava sequence by the socalled magnetite-bearing marker (see below). The upper pillow-lava sequence has been subdivided into several units which are separated by thin, but persistent sheets of ultramafic rocks of presumed intrusive origin (Chadwick, 1986). Intercalated in the mafic volcanics are frequent sulphide-rich metasedimentary horizons with disseminated and massive to semi-massive pyrite, which locally are fuchsite stained. These sulphide-rich zones are up to $50 \mathrm{~m}$ thick and can be traced for several kilometres along strike.

The magnetite-rich marker, which subdivides the volcanic pile of the Ivisârtoq area, is a sequence up to $50 \mathrm{~m}$ wide, which so far has been traced for well over $7 \mathrm{~km}$. The sequence consists of a magnetite-bearing greenish schistose rock up to $10 \mathrm{~m}$ thick, which locally displays lapilli-like structures (Chadwick, 1986). The marker horizon furthermore includes white to light grey metasediments which are either metamorphosed sediments or acid volcanics. Very thin tourmaline layers occur in some of the metasedimentary beds. In the marker horizon there is also a horizon of skarn up to $20 \mathrm{~m}$ wide, which has been traced at intervals for well over $3 \mathrm{~km}$. In this skarn horizon extensive scheelite occurrences have been found (see below). Malachite staining together with small amounts of sulphides such as pyrrhotite and chalcopyrite have been observed in the magnetic marker.

After deposition of the volcanic rocks and sediments the sequence has been repeatedly deformed, metamorphosed and intruded by numerous large pegmatite bodies. The pegmatites intruded at an early stage and have been strongly deformed. Rare examples of thin postdeformational pegmatites do however occur. The supracrustal rocks have been metamorphosed under amphibolite-facies conditions.

The supracrustals have been affected by extensive skarn alteration, whereby the amphibolites as well as the metasediments have been replaced by calc-silicates. In some places the amphibolites have been completely replaced, but usually they have been only partly replaced, with the central parts of pillows replaced and the outer parts of the pillows intact. Skarn is also frequently developed as clearly discordant patches and veins cross-cutting the amphibolites and metasediments.

There appear to be two distinct types of skarn, of which the most common occurs as patches of calc-silicates, while the less common type mainly occurs as distinct bands of garnet-rich calc-silicates. These garnet skarns are generally stratabound and scheelite bearing. The time of skarn formation is still uncertain, but it predates the deformation. 


\section{Stream sediment sampling}

During the field season of 1987 only four stream sediment samples were collected in the Ivisârtoq area, but all of them contained high amounts of scheelite. The samples were collected in the same way as the previous samples from the Godthåbsfjord area (Appel, 1988), which involves sampling of 10 to $30 \mathrm{~kg}$ of gravel and sand which is sieved with a $1 \mathrm{~mm}$ mesh, and the fine material is then concentrated by panning. In the final heavy mineral concentrates the number of scheelite grains are counted after drying the sample. One of the collected samples contained 80 grains of scheelite per litre of fines, while the other samples contained well over 500 grains of scheelite per litre. These scheelite anomalies are the highest so far recorded in the Godthåbsfjord area (Appel, 1988). It is nevertheless quite clear that none of the scheelite-rich horizons located in the Ivisârtoq area (see below) would have been found by stream-sediment sampling alone. The drainage pattern in this area is poorly developed, and the streams generally carry only small amounts of sediment.

\section{Scheelite occurrences}

Field work with ultra-violet light was carried out for about three weeks in the Ivisârtoq area, involving an almost complete traverse across the whole supracrustal belt, and also detailed work in specific areas.

Scheelite is widely distributed throughout the lower as well as the upper sequence of pillow lavas where it occurs as small disseminated grains, but it is generally in small amounts. Scheelite is often found to be particularly abundant in the central part of pillows which have been wholly or partly replaced by skarn. In such pillows the scheelite mostly occurs in the central part of the pillows. Scheelite is also often seen in skarn patches replacing the amphibolites.

In the amphibolites, massive scheelite is found locally in clearly discordant veins which can be traced for a few tens of metres along strike. Scheelite is furthermore found as porphyroblasts up to $10 \mathrm{~cm}$ long and as joint coatings in the amphibolites. It is apparently equally abundant in the lower and upper sequence of metamorphosed pillow lavas.

From an economic point of view the most interesting scheelite occurrences are found in garnet-bearing skarn horizons. One scheelite-rich garnet skarn has been found interlayered in the lower amphibolite sequence. This horizon is about $1 \mathrm{~m}$ wide and was traced for about $50 \mathrm{~m}$ along strike.

This horizon lies juxtaposed to the magnetite-bearing schistose rock in the marker horizon. A skarn horizon up to $20 \mathrm{~m}$ wide, which has been traced for well over 3 $\mathrm{km}$ along strike, is garnetiferous and hosts extensive disseminated scheelite yielding a high grade. The garnet skarn horizon contains bands up to $4 \mathrm{~m}$ thick with high amounts of scheelite. The average width of the wellmineralised garnet skarn is of the order of one to two metres. The scheelite in these 'high grade' bands is mostly medium to rather coarse grained, and displays a white to light yellowish fluorescence indicating a molybdenum content of the order of $1 \%$.

There was inadequate time for a systematic chipsampling programme so no estimates are be presented on the grade of this 'high grade' zone. However, analysis of 12 grab samples yielded an average of $0.97 \%$ tungsten with a range of 0.15 to $1.91 \%$ (Appel, 1988).

\section{Discussion}

A detailed discussion of the genesis of the scheelite in the Ivisârtoq area is premature. In the Malene supracrustal rocks of the outer Godthåbsfjord area quite extensive stratabound scheelite mineralisation has been found in banded amphibolites and in tourmalinites (Appel \& Garde, 1987), and it has been shown that this scheelite mineralisation is of submarine exhalative origin and that the scheelite precursor was precipitated on the sea floor contemporaneously with the deposition of the mafic tuffs and the chemical precipitation of the tourmaline precursor in the tourmalinites (Appel \& Garde, 1987).

In the Ivisârtoq area the scheelite is generally stratabound and the highest scheelite concentrations occur at the same stratigraphic level as the tourmaline-banded metasediments. It is thus realistic to invoke the same origin for the scheelite occurrences in the Malene supracrustals at Ivisârtoq as in the other parts of the Malene supracrustal belt.

Acknowledgements. Charlotte Clausen assisted in the field work and E. Leonardsen, Geological Institute, University of Copenhagen made X-ray identification of scheelite from the Ivisârtoq area.

\section{References}

Appel, P. W. U. 1988: Heavy mineral concentrates from stream sediments collected in the Nuuk area, West Greenland during the period 1982-1987. Grønlands geol. Unders. Open File Ser. 88/1.

Appel, P. W. U. \& Garde, A. A. 1987: Stratabound scheelite and stratiform tourmalinites in the Archaean Malene supracrustal rocks, southern West Greenland. Bull. Grønlands geol. Unders. 156, 26 pp.

Chadwick, B. 1986: Malene stratigraphy and late Archaean structure: new data from Ivisârtoq, inner Godthåbsfjord, southern West Greenland. Rapp. Grønlands geol. Unders. 130, $74-85$. 